\title{
PENERAPAN KARAKTER TOLERANSI BERAGAMA PADA MASYARAKAT CIGUGUR KUNINGAN YANG PLURALIS
}

\author{
Elisabeth Djuniasih dan Aceng Kosasih \\ Universitas Pendidikan Indonesia \\ Email: abeth1306@upi.edu
}

\begin{abstract}
Abstrak: Toleransi merupakan modal utama dalam membangun harmoni antarumat beragama, terutama di Indonesia. Penelitian ini dilakukan untuk mengetahui bagaimana penerapan karakter toleransi beragama dalam kehidupan masyarakat Cigugur yang pluralis. Penelitian di lakukan di Desa Cisantana dan Desa Cigugur, Kecamatan Cigugur, Kabupaten Kuningan, Jawa Barat. Pengumpulan data dalam penelitian ini menggunakan teknik observasi dan wawancara. Analisis data dilakukan dengan teknik analisis deskriptif kualitatif. Hasil penelitian menunjukkan bahwa masyarakat Cigugur yang memiliki keberagaman dalam memeluk agama dapat hidup berdampingan secara damai. Adapun faktor pemersatu masyarakat Cigugur yaitu adanya saling menghargai karena memiliki ikatan darah yang kuat. Selain itu, pemimpin masing-masing agama dan aliran kepercayaan sangat berperan dalam terbentuknya toleransi beragama. Hari Raya Idul Fitri, Upacara Seren Taun, dan Perayaan Natal adalah saat-saat mereka bekerja sama tanpa mengganggu kegiatan beribadah. Kegiatan-kegiatan tersebut merupakan pembelajaran bagi para remaja dan anak-anak karena mereka adalah generasi penerus yang harus mempertahankan toleransi beragama di daerah di mana mereka dilahirkan.
\end{abstract}

Kata Kunci: karakter, toleransi beragama, dan masyarakat pluralis

\section{APPLICATION OF CHARACTER OF RELIGIOUS TOLERANCE IN PLURALIST COMMUNITIY OF CIGUGUR KUNINGAN}

\begin{abstract}
Tolerance is the main capital in building harmony among religious believers, especially in Indonesia. This research was conducted to find out how the application of the character of religious tolerance in the life of the pluralist Cigugur community. The research was conducted in the villages of Cisantana and Cigugur, Cigugur Subdistrict, Kuningan District, West Java. Data collection in this study uses observation and interview techniques. Data analysis was performed using qualitative descriptive analysis techniques. The results of the study show that the Cigugur people who have diversity in embracing religion can coexist peacefully. The unifying factor of the Cigugur community is mutual respect because it has strong blood ties. In addition, the leaders of each religion and the flow of beliefs play an important role in the formation of religious tolerance. Eid al-Fitr, Seren Taun Ceremony, and Christmas Celebration are times when they work together without interfering with worship activities. These activities are learning for young people and children because they are the next generation who must maintain religious tolerance in the area where they are born.
\end{abstract}

Keywords: character, religious tolerance, pluralist society

\section{PENDAHULUAN}

Sudah menjadi kenyataan hingga dewasa ini bahwa macam-macam agama dan aliran kepercayaan semakin marak di belahan dunia mana pun. Setiap agama dan aliran kepercayaan mempunyai misi sebagai pembawa persatuan dan perdamaian, bukan saja untuk antarmanusia, melainkan juga untuk semua makhluk ciptaan Tuhan yang menghuni alam semesta ini. Diharap- kan dengan adanya agama dan iman atau kepercayaan, semua makhluk hidup berdampingan sesuai dengan misi agama dan kepercayaan. Namun, pada kenyataannya misi tersebut tidak selalu berjalan mulus karena selain sebagai pembawa persatuan dan perdamaian, agama dan aliran kepercayaan pun justru menjadi salah satu unsur dalamsebuahkonflik. Eksistensi keberagaman dalam hal beragama di Indonesia juga 
harus ditanamkan sejak dini di kalangan masyarakat Indonesia, terutama kepada siswa di sekolah (Mumpuniarti, 2012). Guru harus menjadi teladan dalam bertoleransi bagi siswanya sehingga kehidupan beragama di sekolah menjadi ajang bagi siswa untuk belajar bertoleransi dalam pluralisme beragama di Indonesia (Palunga \& Marzuki, 2017).

Schimmel (Kahmad, 2009:169) menyebutkan bahwa ada dua unsur yang menyatu dalam agama yaitu pemersatu sosial dan konflik. Salah satu yang menjadi problem paling besar dalam kehidupan beragama dewasa ini yaitu kenyataan pluralisme yang perlu mendapatkan pemahaman dari masyarakat agar teologi suatu agama mendefinisikan diri di tengah-tengah agama lain. Dengan mengedepankan karakter toleransi, masyarakat prulalis akan dapat mengatasi problem beragama tersebut. Karakter toleransi diartikan sebagai sikap dan tindakan yang menghargai perbedaan agama, suku, etnis, pendapat, sikap, dan tindakan orang lain yang berbeda dari dirinya. Toleransi diartikan sebagai suatu kualitas sikap membiarkan adanya pendapat, keyakinan, adatistiadat, dan perilaku orang lain yang berbeda dengan dirinya (Sidharta, dkk, 2009: 14). Dalam kehidupannyata, keinginan, pendapat, dan perilaku seseorang tak ada yang persis sama dengan orang lain, bahkan orang kembar sekali pun.

Mengingat bahwa tiap agama dan kepercayaan bukan merupakan tujuan akhir manusia, melainkan hanya alat pemersatu manusia dengan Tuhan, maka seyogyanyalah agama menjalankan fungsi pembelajaran terhadap pribadi dan perkembangan pribadi manusia dalam hubungannya dengan Tuhan. Sebab itu pada satu pihak perlu dijamin kebebasan bagi tiap usaha yang wajar yang dilakukan oleh tiap-tiap golongan agama untuk membina kepribadian dan perkembangan kepribadian tiap-tiap anggota sesuai dengan keyakinannya (Budiyono, 1983:19).

Ada banyak etnis atau suku tertentu bahkan dari suku tersebut masih memilah lagi menjadi subsuku di Indonesia ini. Di Indonesia terdapat bermacam-macam suku, beragam adat istiadat, juga keberagaman agama dan kepercayaan. Indonesia saat ini memiliki banyak ras, banyak suku, budaya, dan multikultur, sehingga tidak hanya "suku asli" di Nusantara saja yang tinggal di Indonesia ini tetapi juga banyak ras lain, seperti ras kaukasian dan ras lainnya (Gumelar, 2016: 70).

Khotimah(2014:122) menyatakan bahwa di Indonesia agama memiliki peran yang sangat penting, karena Indonesia adalah negara "agama." Pancasila sebagai dasar negara Indonesia menuntut tidak ada orang yang tidak beragama di Indonesia. Untuk mengetahui peranagama dalam pembentukan civil society, perlu kiranya diketengahkan pembahasan tentang agama, khususnya di Indonesia. Walaupun masyarakat Indonesia begitu beragam, namun mereka dapat hidup berdampingan dengan damai. Tidak bisa dipungkiri bahwa dalam beberapa hal masih ada konflik yang kadang-kadang bersifat merongrong, terutama konflik agama.

Berbeda dengan daerah-daerah lain di Indonesia, keberagaman dalam masyarakat Cigugur tidak pernah menimbulkan konflik yang berarti. Isu sara yang menjadi penyulut api perpecahan tak pernah terlihat. Masyarakat hidup dengan sikap toleransi yang menyampingkan kepentingan pribadi dan golongan. Masyarakat Cigugur saling menghargai satu sama lain (Syaripulloh, 2014: 66). Perbedaan agama tidaklah menjadikan mereka hidup dalam ketegangan hingga menimbulkan suatu konflik seperti konflikkonflik yang sering terjadi dewasa ini yang 
dilatarbelakangi oleh perbedaan agama. Kehidupan mereka justru sangat harmonis dan sangat menjunjung tinggi pluralisme beragama. Selain mengakui keberadaan hak agama lain, mereka juga terlibat dalam usaha memahami perbedaan dan persamaan dari setiap masing-masing penganut agama yang ada. Faktanya, bahwa setiap masyarakat yang berbeda agama tersebut dapat berinteraksi secara positif dalam lingkungan yang majemuk. Adapun faktor pemersatu masyarakat Cigugur adalah pemimpin masing-masing agama dan ketua aliran kepercayaan serta ikatan darah di antara masyarakatnya.

Berangkat dari ketertarikan fenomena tersebut, melalui obervasi dan wawancara, penulis ingin mengkaji secara mendalam bagaimana karakter toleransi beragama yang diterapkan pada masyarakat Cigugur. Masyarakat Cigugur yang pluralis sudah banyak diteliti oleh para peneliti sebelumnya. Salah satunya oleh M. Hisyam (Isma'il, 2004) yang mengkaji religi dan pandangan hidup masyarakat. Selain M. Hisyam, Wawan Hernawan meneliti dengan menitikberatkan komunikasi dalam toleransi beragama. Hernawan (2010) menjelaskan bahwa untuk menciptakan toleransi (kerukunan hidup) antarumat berbeda agama, faktor komunikasi memegang peranan penting. Melalui kajian komunikasi antarbudaya, diharapkan dapat terbentuk adanya sikap saling percaya dan saling menghormati antarpemeluk agama sebagai bangsa yang berbudaya dalam rangka memperkokoh hidup berdampingan secara damai, dapat menerima perbedaan, budaya sebagai berkah daripada bencana, melakukan upaya damai dengan mereduksi perilaku agresif, dan mencegah terjadinya konflik yang dapat merusak peradaban dengan cara menciptakan forum-forum dialog, untuk mencapai kesepahaman.
Dialog digambarkan sebagai keterbukaan pandangan antara orang-orang yang memiliki kepedulian terhadap satu sama lain. Dialog antarumat beragama merupakan salah satu wujud keserasian dan keharmonisan, karena adanya pandangan dan pendekatan positif antara satu pihak dan pihak yang lain. Dialog akan menghasilkan pengukuhan keserasian dan saling pengertian (Zarkasi, 2018).

Toleransi adalah sikap dan tindakan yang menghargai perbedaan agama, suku, etnis, pendapat, sikap, dan tindakan orang lain yang berbeda dari dirinya. Toleransi adalah sikap menerima dengan kepenuhan hati akan keberadaan setiap warga bangsa Indonesia dengan seluruh perbedaan latar belakang agama, suku bangsa, dan budaya yang dimilikinya (Suseno, 1998:11). Toleransi mengedepankan rasa saling menghormati antara individu yang satu dan yang lain (Widiya, 2014). Contoh karakter toleransi adalah tidak mengganggu orang lain yang berbeda pendapat, menghormati orang lain yang berbeda adat-istiadatnya, bersahabat dengan teman lain tanpa membedakan agama, suku, dan etnis, dan mau menerima pendapat yang berbeda dari orang lain.

Harmoni dalam hidup keberagaman hanya mungkin terwujud jika sikap toleransi secara konsisten diterapkan. Bahkan lebih dari itu, toleransi adalah suatu kebiasaan yang merupakan bagian dari kebudayaan bangsa Indonesia yang menerima keberagaman dengan penuh ketulusan. Toleransi adalah gaya hidup ciri khas bangsa Indonesia. Dalam hidup keberagaman, toleransi merupakan syarat yang mesti dipenuhi untuk memelihara dan melindungi, tidak saja keberagaman, tetapi persatuan itu sendiri. Dengan kata lain, persatuan negeri ini hanya mungkin terjaga jika keberagaman identitas primordial setiap warga bangsa Indo- 
nesia sepenuhnya diakui dan diberi ruang untuk mengembangkan diri. Kondisi itu sepenuhnya bergantung kepada kesadaran setiap warga bangsa untuk terus bersikap toleran. Itu artinya, semangat menerima perbedaan dalam sikap toleransi adalah sebuah modal dasar bagi setiap orang dengan segenap keunikan identitasnya dapat hidup baik merealisasikan dirinya.

Toleransi, tidak cukup diidentifikasi sebagai sebuah sikap, melainkan suatu kesadaran, suatu cara berpikir yang kekhasannya terletak pada kemauan untuk saling menerimadan menghormati perbedaan. Toleransi sangat memerlukan sarana edukasi agar terus terbina sebagai kepribadian khas bangsa Indonesia yang secara konsisten harus ditanamkan kepada setiap generasi bangsa untuk menjamin persatuan negeri dan bangsa. Hal krusial yang sama sekali tak dapat diabaikan.

Penelitian ini bertujuan untuk mendeskripsikan cara penerapan karakter toleransi beragama pada masyarakat Cigugur. Di samping itu, penelitian ini juga berupaya mengidentifikasi kegiatan-kegiatan yang mendeskripsikan karakter toleransi beragama pada masyarakat Cigugur.

\section{METODE}

Penelitian ini merupakan penelitian deskriptif kualitatif. Subjek yang diteliti dalam penelitian ini ialah masyarakat Cigugur Kabupaten Kuningan Jawa Barat. Penelitian dilakukan di Desa Cisantana dan Desa Cigugur, Kecamatan Cigugur, Kabupaten Kuningan, Jawa Barat yang berjarak sekitar 3,5 km dari Ibu Kota Kabupaten Kuningan. Wawancara dilakukan terhadap beberapa tokoh masyarakat Cigugur. Jumlah pihak yang diwawancarai semuanya yaitu lima orang, dan dari wawancara itu diharapkan diperoleh informasi yang relevan dan men- cukupi terkait dengan pokok pembahasan dalam penelitian ini.

Ada dua jenis data dalam penelitian ini, yaitu data primer dan data sekunder. Data primer dikumpulkan dengan teknik wawancara dan pengamatan di lapangan, sedangkan data sekunder diperoleh melalui penelusuran kepustakaan. Data yang dikumpulkankemudian dianalisis secara kualitatif.

\section{HASIL DAN PEMBAHASAN \\ Hasil}

Pada hari Rabu tanggal 31 Oktober 2018 pukul 04.00 dini hari, penulis berangkat ke Kuningan untuk mengadakan penelitian di Kecamatan Cigugur. Dalam wawancaranya, peneliti memperoleh keterangan dari beberapa narasumber yang memperkuat penelitian-penelitian sebelumnya tentang keadaan masyarakat yang pluralis walaupun ditinjau dari berbagai sudut pandangan.

Pertama kali peneliti menemui Bapak Ari Rianto. Beliau adalah sekretaris desa Cisantana Kecamatan Cigugur. Beliau mengatakan bahwa Desa Cisantana merupakan bagian dari Kecamatan Cigugur. Kecamatan Cigugur adalah salah satu kecamatan di Kabupaten Kuningan yang terletak \pm 3,5 Km sebelah barat dari pusat kota Kabupaten Kuningan. Kecamatan Cigugur terletak di kaki Gunung Ciremai bagian timur. Lahan di wilayah Kecamatan Cigugur pada umumnya digunakan sebagai pemukiman, pertanian, ladang, peternakan, kolam, fasilitas pemerintahan, pendidikan, tanah $\mathrm{ku}-$ buran, hutan, tempat ibadah, tempat pariwisata, serta fasilitas umum lainnya.

Dalam kehidupan beragama, Kecamatan Cigugur merupakan suatu wilayah yang penduduknya memeluk beraneka ragam agama. Sebagian besar penduduk memeluk agama Islam, Katolik, dan meme- 
luk aliran kepercayaan yang disebut ADS (Agama Djawa Sunda). Ada beberapa warga yang memeluk agama Kristen, Buddha, dan Hindu walaupun tidak terlalu banyak. Walaupun beragam, mereka hidup rukun dan damai karena karakter toleransi beragama sudah mendarah daging dalam jiwa mereka. Menurut Bapak Ari Rianto kunci kerukunan di Cigugur adalah saling membantu dengan sesama, tidak pernah menghujat orang lain, tidak pernah memaksakan suatu agama kepada orang lain, tidak pernah mendoktrin, tidak mudah terpengaruh, tidak memicu terjadinya konflik, dan tidak membawa isu agama saat bermusyawarah. Masyarakat bisa hidup berdampingan walau memiliki agama yang berbeda-beda yakni Islam, Katolik, dan Penghayat (ADS) karena tidak pernah saling mengganggu ritual agama masing-masing dan selalu saling membantu saat ada tetangga yang membutuhkan. Misalnya, ada yang orang yang "live in" di rumah warga, maka mereka menjamu tamu tersebut dengan baik, tidak peduli apakah tamu dan pemilik rumah agamanya sama atau berbeda.

Meskipun saat ini di media sosial banyak terjadi konflik masyarakat karena masalah agama, namun hal itu tidak berpengaruh bagi kerukunan masyarakat Cigugur, karena semua warga memiliki sifat tidak mudah terpengaruh. Di saat ada isu yang sekiranya akan memicu konflik, maka semua warga akan berusaha untuk meredam isu tersebut. Ketika ada salah satu tempat ibadah yang butuh perbaikan, maka semua warga akan gotong-royong membantu tanpa melihat itu untuk tempat ibadah orang Islam, Katolik, atau Kepercayaan.

Berikutnya peneliti menemui Bapak Darsono yang merupakan tokoh agama Islam di Cigugur. Beliau menyatakan bahwa masyarakat di Cigugur bisa hidup rukun walau anggota masyarakatnya berbeda agama. Dalam acara Seren Taun yang merupakan acara tahunan terutama bagi aliran kepercayaan ADS, semua warga ikut berpartisipasi, tanpa memandang agama dengan mencari dana untuk pelaksanaan Seren Taun tersebut. Dengan prinsip kebersamaan dan tidak membeda-bedakan orang, akan terbentuk rasa nyaman untuk semua anggota masyarakat. Contoh lainnya yaitu saat ada yang meninggal, tidak peduli agama apa yang dianutnya, maka semua tetangga akan ikut mengantarkan ke pemakaman. Keanekaragaman agama yang dipeluk oleh penduduk di Cigugur tidak menyebabkan hubungan antarpemeluk yang berbeda agama renggang dan kaku, sikap toleransi dan saling menghargai diantara mereka justru nampak harmonis. Keharmonisan hubungan, juga dibuktikan dengan adanya kerja sama dan sikap saling gotongroyong antarumat beragama dalam pembangunan berbagai rumah ibadah di Cigugur. Seperti yang diungkapkan oleh Bapak Darsono, bahwa Mesjid Al-Hidayah yang didirikan pada tahun 2005 ini dibangun di wilayah yang mayoritas warganya adalah penganut Katolik, namun mereka berusaha membantu pendirian mesjid guna memudahkan masyarakat muslim dalam beribadah. Selama proses pembangunan mesjid Al-Hidayah tersebut, bukan hanya masyarakat muslim saja yang terlibat, masyarakat nonmuslim pun ikut bersama-sama membantu pembangunannya.

Berikutnya peneliti mewawancarai Rama Andreas Dedi, OSC yang biasa dipanggil Rama Dedi. Beliau adalah imam Katolik yang memimpin umat Katolik Paroki Kristus Raja yang terletak di Jalan Rumah Sakit, Cigugur. Beliau adalah orang Sunda asli berasal dari Ciamis yang berkarya di Tatar Sunda sebagai seorang biarawan. Beliau banyak bercerita tentang bagaimana awal masyarakat Cigugur banyak 
yang memeluk agama Katolik. Gereja Katolik Cigugur merupakan salah satu gereja yang terletak di Tatar Sunda. Menjadi Katolik bagi orang Sunda di Cigugur merupakan kisah tersendiri yang menarik.

Dikisahkan tentang peristiwa masuknya sejumlah masyarakat Sunda yang semula penganut aliran kepercayaan, yang dikenal sebagai Agama Djawa Sunda (ADS) ke dalam Gereja Katolik. Peristiwa itu terjadi ketika pembubaran sebuah organisasi religius lokal yang dilakukan oleh pemerintah sehingga berdampak pada aliran kepercayaan ADS oleh pemimpinnya yaitu Pangeran Tedja Buana. Pembubaran aliran kepercayaan ADS ini dituangkan dalam Surat Pernyataan yang ditulis di Cirebon pada bulan September 1964. Selain situasi politis, menurut banyak sumber, pembubaran ADS dan perpindahan mereka ke agama Katolik itu dikaitkan dengan adanya penafsiran atas wahyu yang disampaikan oleh P. Madrais kepada sekelompok pengikutnya di sekitar Curug Goong, yang berbunyi: "Isuk jaganing geto anjeun baris nyalindung handapeun Camara Bodas anu bakal ngabeberes alam dunya" (Esok di kemudian hari engkau akan berlindung di bawah Cemara Putih yang akan menata alam dunia). Muncullah beragam penafsiran atas wahyu "Camara Bodas". Ada yang menganggap bahwa yang dimaksud adalah "imam Katolik", karena mereka selalu berjubah putih. Ada juga yang mengaitkannya dengan pohon cemara yang bersalju (putih) yang dipajang untuk merayakan hari Natal. Ada yang memaknai wahyu tersebut sebagai "Kristus". Pada umumnya makna "Camara Bodas" sebagai "Kristus" lebih diterima oleh umat Katolik eksADS, seperti dikatakan oleh Basuki Nursananingrat (menantu P. Tedja Buana) bahwa ia sendiri menanyakan langsung kepada P. Tedja Buana setelah ADS dibubarkan.
Lalu bagaimana hubungan yang terjadi antara Gereja Katolik dan mantan aliran kepercayaan ADS sehingga sebagian besar mantan aliran kepercayaan ADS memeluk agama Katolik? Pada tahun 1960-an awal, di Cigugur tidak ada seorang Katolik pun; apalagi bangunan gereja. Gereja Katolik masih "asing" bagi masyarakat Cigugur. Agama yang cukup dominan adalah Islam dan Agama Djawa Sunda (ADS). Ada ribuan umat ADS di Desa Cigugur dan desadesa di sekitarnya, termasuk di beberapa desa di kabupaten lain di Jawa Barat dan Desa Cigugur sendiri adalah pusatnya, dengan adanya Gedung Paseban Tri Panca Tunggal sebagai bangunan pusat ADS. Ketika ada Upacara Seren Taun, Gereja Katolik pun ikut bersyukur dengan mengadakan ibadat keagamaannya sendiri yang disebut Misa syukur. Dalam Misa syukur mereka menggunakan bahasa Sunda sebagai bahasa pengantar dengan lagu-lagu Sunda yang diiringi oleh gamelan. Imam dan para petugas lainnya menggunakan pakaian daerah sehingga suasana Sunda sangat terbangun, apalagi dekorasi gereja pun bernuansa Sunda. Biasanya setelah Misa syukur di gereja, pastur kepala paroki akan bergabung dalam acara doa lintas agama dan kepercayaan, dan melantunkan doa secara Katolik di Gedung Paseban. Rama Dedi mengatakan secara berkala mereka mengadakan pertemuan untuk membicarakan banyak hal yang berhubungan dengan keharmonisan kehidupan masyarakat dalam wadah FKUB (Forum Kerukunan Umat Beragama). Bahkan beberapa kali Rama Dedi yang notabene seorang pemimpin umat Katolik diundang untuk menjadi narasumber di Universitas Islam di Kabupaten Kuningan atau di Cirebon. Dalam acara tersebut, tidak hanya pemimpin agama Katolik yang diminta untuk menjadi narasumber, tetapi juga dari agama 
lainnya. Itulah bukti kentalnya toleransi beragama di antara mereka.

Selanjutnya kami mewawancarai Ibu Ela Romlah. Ibu Ela adalah salah seorang bidan Puskesmas Desa Cisantana yang kami temui di rumahnya setelah lepas dari tugasnya. Beliau adalah orang Bandung yang bersuamikan orang Cisantana. Ibu Ela adalah seorang penghayat. Penghayat artinya penganut aliran kepercayaan Sunda Wiwitan atau ADS. Yang mengejutkan bagi kami, ternyata suami dan kedua anak Ibu Ela menganut Agama Katolik. Perbedaan dalam satu keluarga tersebut tidak memengaruhi kerukunan keluarga mereka. Tampak sikap toleransi yang besar ditunjukkan oleh keluarga tersebut. Dalam obrolan kami Beliau banyak mengungkapkan tentang aliran Sunda Wiwitan atau ADS yang dianutnya. Ibu Ela menjelaskan arti ADS sebenarnya. Orang di luar ADS sering kali merasa salah mengerti tentang aliran kepercayaan ini. Pada umumnya orang di luar ADS menganggap bahwa ADS adalah singkatan dari Agama Djawa Sunda, yang diartikan sebagai agama milik orang Jawa dan orang Sunda. Padahal Agama Djawa Sunda ini adalah akronim dari sebuah ungkapan, yaitu " $A n$ jawat lan anjawab roh susun-susun kang den tunda" (memilih dan menyaring roh yang tersusun dan yang tertunda, yang ada di seluruh alam semesta termasuk dalam diri manusia). Yang dimaksud dengan "memilih" dan "menyaring" ini adalah sebuah tindakan manusia yang berlangsung dalam proses "meditasi" atau "semedi". Tujuan tindakan ini adalah untuk "menyempurnakan" roh-roh tersebut supaya menjadi roh yang layak atau pantas bagi manusia dan mencerminkan kemanusiaan.

Setiap bulan Rayagung masyarakat di Cigugur merayakan Upacara Adat Seren Taun. Pada dasarnya Upacara Seren Tahun adalah upacara syukur panen padi yang dilaksanakan masyarakat Sunda khususnya di wilayah desa Adat Sunda. Di Kuningan sendiri, upacara ini dilakukan oleh komunitas masyarakat di Desa Cigugur. Upacara Seren Taun di Desa Cigugur Kuningan dipusatkan di Pendopo Paseban Tri Panca Tunggal tempat kediaman Pangeran Djatikusumah. Bulan Rayagung adalah bulan terakhir dalam penanggalan kalender Sunda kuno. Upacara Seren Taun sarat akan nilai-nilai sakral, budaya, kesenian, dan pendidikan. Seren Taun merupakan salah satu warisan budaya masyarakat agraris Jawa Barat sebagai ungkapan rasa syukur pada Tuhan Yang Maha Esa atas hasil panen dalam setahun. Upacara Seren Taun merupakan acara penyerahan hasil bumi berupa padi untuk disimpan ke dalam lumbung atau dalam bahasa Sunda disebut leuit. Dalam ceritanya, Ibu Ela menjelaskan bahwa setiap umat Katolik merayakan Natal, yang piket di sekitar gereja adalah bapak-bapak dari agama Islam dan kaum penghayat. Ibu-ibu dan anak-anak menyediakan konsumsi bagi umat Katolik yang selesai merayakan ibadat agamanya. Begitu juga sebaliknya, ketika umat Islam merayakan hari raya Idul Adha, umat Katolik dan penghayat membantu memotong kurban. Ketika umat penghayat merayakan Upacara Seren Tahun, umat Katolik dan umat Muslim pun turut bersyukur atas berkat yang mereka terima dengan merayakannya sesuai ajaran mereka. Tampak sekali toleransi beragama yang begitu kuat di antara masyarakat Cigugur.

Terakhir sebelum kembali ke Bandung, peneliti mengunjungi Ibu Christina Nina di rumahnya, yaitu di desa Cigugur. Ibu Nina adalah seorang pegawai negeri beragama Katolik yang mengajar di SDN 2 Cisantana, Kecamatan Cigugur, Kabupaten Kuningan. Ibu Nina lahir dan berkarya di Cigugur setelah menimba ilmu di SPG San- 
ta Angela, Bandung. Ketika ditanya tentang pendidikan karakter di sekolah di tempat dia mengajar, Beliau menceritakan bahwa yang nomor satu ditanamkan adalah karakter toleransi karena peserta didiknya berasal dari dua agama besar (Islam dan Katolik) dan 1 kepercayaan. Toleransi dipraktikkan dalam proses pembelajaran dan menjadi budaya sekolah. Para guru harus memiliki prinsip menghargai perbedaan, menyemai keragaman, dan menguatkan nilai-nilai kebangsaan. Tidak sulit menanamkan karakter toleransi karena dalam keluarga peserta didik, sikap tersebut sudah ditanamkan sejak lahir. Sejak kecil anakanak ikut dengan orang tuanya yang berkegiatan bersama dengan masyarakat yang pluralisme. Ketika anak duduk di bangku sekolah, guru hanya menguatkan saja. "Untuk meningkatkan toleransi dalam masyarakat, masing-masing dari kita harus mengamalkan dengan benar dan sungguh-sungguh ajaran agama kita sendiri dan mengamalkan Pancasila serta menghormati pemeluk agama lain. Kita tidak boleh menghina atau melecehkan orang lain karena perbedaan SARA. Jadi, toleransi dengan menghormati pemeluk agama lain serta ajarannya akan selalu terwujud di Cigugur asalkantakada campur tangan pihak lain di luar Cigugur karena kepentingan politik," ungkapnya. "Toleransi bukan berarti kita ikut serta mengamalkan ajaran agama lain, tapi toleransi adalah menghormati keyakinan atau kepercayaan orang lain," pungkasnya.

Ketika peneliti berjalan dari rumah satu ke rumah lainnya, penulis mengamati beberapa peristiwa yang membuktikan bahwa apa yang diungkapkan oleh para narasumber benar adanya. Ketika suara azan berkumandang, sebagian anak-anak berlari ke masjid untuk salat, sementara anak lainnya menjaga barang anak-anak yang sedang salat. Peneliti bertanya kepada salah seorang anak yang tidak salat, "Mengapa kalian tidak salat?" Mereka menjawab bahwa mereka bukan muslim. Mereka beragama Katolik. Mereka bertoleransi kepada teman-teman mereka untuk menjalankan ibadah mereka.

Ketika peneliti berkendara umum dari Cisantana ke Cigugur, di dalam angkot berjumpa dengan seorang kawan lama yang beragama Katolik bersama dengan anaknya yang berhijab. Kawan lama itu bernama Ibu Agnes. Ternyata ibu dan anak memeluk agama yang berbeda, namun tampak jelas tak ada kesenjangan di antara mereka. Pemandangan semacam itu merupakan pemandangan yang biasa di Cigugur. Seperti yang dikatakan Ibu Ela, dalam satu keluarga terdiri dari beberapa agama dengan tidak mengganggu pelaksanaan ibadah masing-masing bukan menjadi hambatan bagi mereka. Mereka berpendapat agama adalah pilihan bukan paksaan, dan yang penting bagi mereka adalah bagaimana hubungan dengan Tuhan dan sesama.

\section{Pembahasan}

Pemerintah daerah sangat berperan serta dalam penerapan karakter toleransi beragama pada masyarakatnya, seperti yang dikatakan oleh Sekdes Cisantana bahwa pemerintah daerah berusaha untuk tidak memaksakan suatu agama kepada orang lain, tidak pernah mendoktrin, tidak mudah terpengaruh, tidak memicu terjadinya konflik, dan tidak membawa isu agama saat bermusyawarah. Dengan dukungan pemerintah daerah, maka toleransi beragama di Cigugur akan terus terpelihara dan akan mengakar kuat.

Begitu pula dengan para pemimpin agama, mereka sepakat untuk mengedepankan toleransi beragama. Hal ini sesuai dengan pendapat Hakim (2013) yang mengatakan pada hakikatnya kerukunan umat 
beragama adalah juga kerukunan masyarakat. Dengan demikian, secara faktual jika kerukunan umat beragama terganggu maka kerukunan dan ketertiban masyarakat akan terganggu pula. Terlebih lagi, kerukunan umat beragama -yang juga kerukunan masyarakat- adalah merupakan pilar terwujudnya kerukunan nasional. Kenyataan demikian menunjukkan bahwa masyarakat Indonesia adalah masyarakat yang beragama. Apabila umat beragama tidak rukun, maka bangsa Indonesia secara keseluruhan akan mengalami disharmoni. Jadi, kerukunan umat beragama adalah juga tanggung jawab Pemerintahan Daerah.

Seperti yang dikisahkan oleh Rama Dedi yang mengatakan bahwa secara berkala mereka mengadakan pertemuan untuk membicarakan banyak hal yang berhubungan dengan keharmonisan kehidupan masyarakat dalam wadah FKUB (Forum Kerukunan Umat Beragama). Pada umumnya pemimpin agama adalah panutan bagi pengikutnya. Jika pemimpin agama memberi teladan dalam toleransi beragama, tentu saja para pengikutnya akan melakukan hal yang sama. Menurut Hasan (2018) dalam acara silaturahmi dengan para peserta $\mathrm{Mu}-$ syawarah Besar Pemuka Agama untuk Kerukunan Bangsa, Jokowi mengajak masyarakat mensyukuri nikmat perdamaian dan kerukunan yang dirasakan di Indonesia. Ia mengingatkan masyarakat tak melupakan nilai-nilai perdamaian yang disebutnya penting. Ia juga mengimbau para pemuka agama terus menjadi teladan bagi umat beragama serta mengedepankan toleransi.

Sebagai panutan umat, Rama Dedi ikut terlibat dalam upacara Seren Taun yang merupakan budaya setempat, umat Katolik yang lain pun turut berperan serta, bukan dalam ibadahnya, tetapi dalam acara pawai, dan sebagainya. Dalam kesempatan khusus umat Muslim dan Katolik melaku- kan ibadah mereka masing-masing turut bersyukur atas rezeki yang melimpah selama setahun berlalu dan memohon berkat untuk tahun berikutnya.

Selain pemerintah daerah dan para pemimpin agama yang membuat karakter toleransi beragama tetap kuat, seperti yang dikatakan Bapak Haji Darsono, ikatan darah di antara mereka pun menjadi salah satu penunjang dalam bertoleransi. Walaupun ada beberapa pendatang, kerukunan karena toleransi tidak mengalami perubahan. Yang terjadi justru para pendatang dengan cepat menyesuaikan diri bahkan kadang-kadang sudah tidak tampak bahwa mereka kaum pendatang. Karena ikatan darah, di hari Idul Fitri, hari Natal, dan di bulan Rayagung, mereka ikut berbahagia merayakannya tanpa harus mengikuti ibadahnya jika bukan agama mereka justru mereka saling menjaga suasana agar tercipta suasana ibadah yang baik dan hikmat.

Seperti ketika upacara Seren Taun, persiapan dan pelaksanaan seren taun dilakukan oleh semua warga Cigugur tanpa memandang agama dan suku, baik yang beragama Nasrani, Katolik, Islam, atau Kepercayaan, semuanya sukarela menyiapkan pesta seren taun. Sistem kerja saling berbagi tugas dan tidak ada pengotak-ngotakan peran berdasarkan keyakinan juga merupakan bentuk toleransi yang tetap terpelihara. Tidak pernah ada perselisihan karena latar belakang agama akibat salah satu pihak merasa dirugikan. Sebab, semua masalah diselesaikan bersama-sama tanpa memandang siapa yang memerlukannya. Keragaman dan persatuan masyarakat juga terlihat dari peserta dan tamu yang hadir karena semua meyakini bahwa Seren Taun merupakan bentuk refleksi bagi masyarakat untuk introspeksi diri, kembali melestarikan alam, dan selalu mengabdi kepada Pencipta. 
Begitu juga ketika memasuki bulan Ramadhan, saat umat Muslim salat tarawih di masjid, umat Nasrani dan penghayat menyediakankolak dan makanan lainnya, agar tiba saatnya berbuka puasa, umat Islam dapat berbuka bersama tanpa harus menyiapkannya terlebih dahulu. Sebaliknya ketika umat nasrani merayakan Natal, umat Muslim berjaga-jaga bersama kesatuan Polsek untuk mengamankan gereja tempat umat Nasrani sedang beribadah.

Dalam berkegiatan yang mencerminkan toleransi keagamaan, para orang tua membawa serta anak-anaknya sehingga secara tidak langsung anak-anak belajar dalam hal bertoleransi. Mereka ikut menari dalam upacara seren Taun, mereka ikut menyediakan kolak dan makanan lainnya, juga turut serta menghias pohon Natal di halaman gereja. Anak-anak bekerja sama tanpa memandang siapa yang sedang dibantunya atau agama apa orang yang sedang dibantunya. Anak-anak tersebut sudah dididik dalam keluarga mereka apa yang boleh mereka lakukan dan apa yang tidak boleh mereka lakukan. Tidak ada anak yang beragama Islam ikut beribadah di gereja, begitu juga sebaliknya tidak ada anak beragama Katolik atau Penghayat yang beribadah di mesjid.

Toleransi masyarakat yang berbeda keyakinan dan kepercayaan di Cigugur yang sudah berlangsung puluhan tahun adalah hal terpenting untuk menciptakan keharmonisan pembangunan. Dengan memiliki sikap demikian, anak-anak penerus bangsa akan menjadi orang dewasa yang kuat dalam bertoleransi.

\section{PENUTUP}

Penerapan pendidikan karakter toleransi beragama pada masyarakat pluralisme di Cigugur, Kuningan, Jawa Barat berjalan dengan baik. Masyarakat di Cigugur da- pat hidup rukun walau tinggal berdampingan dengan tetangga yang berbeda agama, yaitu agama Islam, Katolik, dan Penghayat (ADS).

Kesuksesan dalam penerapan pendidikan karakter tersebut karena semua warga percaya bahwa semua agama pada dasarnyamengajak kepada kebaikan, mau memahami agama orang lain sehingga tidak menimbulkan praduga/prasangka terhadap ritual agama orang lain (literasi agama), adanya ikatan darah, rasa kekeluargaan, dan rasa persaudaraan yang kuat, saling membantu antar warga dan antar tetangga, melakukan gotong-royong dalam pembangunan fasilitas keagamaan maupun fasilitas umum.

Semua itu diperoleh karena pemerintah daerah dan para pemimpin agama selalu berupaya mengedepankan persatuan dengan tidak pernah memicu konflik terutama tentang isu agama. Ketika di daerah lain mengalami kericuhan karena masalah agama, mereka berusaha untuk tidak terpengaruh. Karena teladan dari pemerintah daerah dan para pemuka agama itulah, maka daerah Cigugur merupakan daerah yang masyarakatnya pluralisme namun selalu hidup berdampingan dengan perbedaan. Perbedaan justru menambah kekayaan budaya bagi masyarakat Cigugur. Semoga daerah-daerah lain dapat bercermin pada kehidupan masyarakat Cigugur yang aman, tentram, dan damai.

\section{UCAPAN TERIMA KASIH}

Puji dan syukur penulis panjatkan kepada Tuhan Yang Maha Kuasa atas anugerah yang telah diberikan sehingga penulis dapat melakukan penelitian sederhana sampai dengan penyusunan artikel ini. Tak lupa peneliti mengucapkan terima kasih kepada semua pihak yang telah membantu baik secara moril dan materil ketika me- 
laksanakan penelitian di Cigugur Kuningan. Tanpa bantuan tersebut tidak akan mungkin penelitian ini terlaksana dan artikel ini terwujud.

\section{DAFTAR PUSTAKA}

Budiyono, A.H. (1983). Membina kerukunan antar umat beragama 2. Yogyakarta: Yayasan Kanisius.

Gumelar, M.S. (2016). Napak tilas marginalisasi berbagai etnis di Indonesia dalam hubungannya dengan Bhinneka Tunggal Ika. Jurnal Studi Kultural, 1(2), 70-78. URL: https://media.neliti.com/media/publications/ 2238 47-napak-tilas-marginalisasi-berbagai-etnis.pdf.

Hakim, B.A. (2013). Peran pemerintah daerah dan kantor kementerian agama dalam pemeliharaan kerukunan umat beragama. Jakarta: Puslitbang Kehidupan Keagamaan Badan Litbang dan Diklat Kementerian Agama RI.

Hasan. (2018). Jokowi imbau pemuka agama jadi teladan umat dan kedepankan toleransi. Jakarta: Obssession News.

Hernawan. (2010). Komunikasi antarumat berbeda agama (Studi kasus sikap sosial dalam keragaman beragama di Kecamatan Cigugur Kabupaten Kuningan Jawa Barat). Diunduh dari http://jurnal.ubl.ac.id/index.php/JIK/article/view/3 69. Tanggal Mengunduh 14 Nov 2018.

Isma'il, I.Q. (2004). Religi lokal \& pandangan hidup: Kajian masyarakat penganut religi Tolotang dan Patuntung, Sipelebegu (Permalim), Samimisme, dan agama Jawa Sunda. Jakarta: LIPI.
Kahmad, D. (2009). Sosiologi agama. Bandung: Remaja Rosda Karya.

Khotimah. (2014). Agama dan civil cociety. Jurnal Ushuluddin, 21(1), 121-132. DOI: http://dx.doi.org/10.24014/jush.v21i1.730.

Mumpuniarti. (2012). Pembelajaran nilai keberagaman dalam pembentukan karakter siswa sekolah dasar inklusi. Jurnal Pendidikan Karakter, 2(3), 248-257. DOI: 10.21831/jpk.v0i3.1231.

Palunga \& Marzuki. (2017). Peran guru dalam pengembangan karakter peserta didik di Sekolah Menengah Pertama Negeri 2 Depok Sleman. Jurnal Pendidikan Karakter, 7(1), 109-123. DOI: 10.21831/jpk.v7i1.20858.

Sidharta, dkk. (2009). Konsep dasar pendidikan anak usia dini. Yogyakarta: Penerbit Logung Pustaka.

Suseno, F.M. (1998). Mencari makna kebangsaan. Yogyakarta: Kanisius.

Syaripulloh.(2014). Kebersamaan dalamperbedaan: Studi kasus masyarakat Cigugur, Kabupaten Kuningan, Jawa Barat. Jurnal Sosio Didaktika, 1(1), 64-78. DOI: $10.15408 /$ sd.v1i1.1207.

Widiya. (2014). Cinta damai: Pengembangan kepribadian dan profesional bidan. Diunduh dari https://widiyacipta.wordpress.com/tag/cinta-damai/.

Zarkasi. (2018). Dialog antarumat beragama dalam upaya pencegahan konflik. Diunduh dari https://www.researchgate.net/publication/326133047_ 